\title{
A Forgotten Italian Physicist at the Turn of the Eighteenth and Nineteenth Centuries: The Sicilian Giovanni Silio Borremans
}

\author{
Roberto Mantovani ${ }^{*}$ (D), Daniela Bartolotta ${ }^{2}$ \\ ${ }^{1}$ Physics Laboratory: Urbino Museum of Science and Technology, Department of "Pure and Applied Sciences", \\ Collegio Raffaello, University of Urbino Carlo Bo, Urbino, Italy \\ ${ }^{2}$ Bonaventura Secusio's High School, Caltagirone, Italy \\ Email: ^roberto.mantovani@uniurb.it, daniela_bartolotta@yahoo.it
}

How to cite this paper: Mantovani, R., \& Bartolotta, D. (2019). A Forgotten Italian Physicist at the Turn of the Eighteenth and Nineteenth Centuries: The Sicilian Giovanni Silio Borremans. Advances in Historical Studies, 8, 148-174.

https://doi.org/10.4236/ahs.2019.84012

Received: July 15, 2019

Accepted: September 16, 2019

Published: September 19, 2019

Copyright $\odot 2019$ by author(s) and Scientific Research Publishing Inc. This work is licensed under the Creative Commons Attribution International License (CC BY 4.0).

http://creativecommons.org/licenses/by/4.0/

\begin{abstract}
We are presenting the scientific work of Giovanni Silio Borremans (1756-1830), a physicist almost unknown to Science historians, who worked in the city of Caltagirone (Sicily) from 1775 until his death, in 1830. An intense archival work has been carried out on this interesting scientist; it has allowed us to discover many unpublished and unknown documents that have shed a new light on Silio's life and on his scientific activity. As visual evidence, a good number of archive images have been inserted in the text. We owe to Silio the origins of experimental physics in Caltagirone, whose good results will be appreciated after his death by his most illustrious scholar, the physicist and naturalist Emmanuello Taranto Rosso. Silio's work started in Caltagirone in 1775 when a teaching chair in experimental physics was established at the ancient $R$. Academy Ferdinando IV; he held it for more than fifty years. Some manuscripts, scientific works and the dictated lessons of this learned and erudite man were found and transcribed by his most famous student, the already mentioned Taranto Rosso, who later will, become his "natural" successor in the teaching of experimental Physic at the Academy.
\end{abstract}

\section{Keywords}

Giovanni Silio Borremans, Guglielmo Silio Borremans, Caltagirone,

Emanuele Taranto Rosso, Academy of Studies, Teaching of

Experimental Physics, Emmanuele Estiller

\section{Introduction}

A first analysis of the scientific work of Giovanni Silio Borremans (1756-1830), 
an almost unknown physicist from Palermo, is going to be presented. He is not mentioned even in the most recent bibliographical repertories dedicated to scientific personalities who worked in Sicily. The analysis has been facilitated by documents that have been found in the archives in the city of Caltagirone (Sicily); almost all of them are manuscripts which are completely new and un-known to Science historians. This work originated from a study that we completed in 2013 on an important collection of historical scientific instruments, today still preserved in the Physics Museum of the Liceo "Bonaventura Secusio" in Caltagirone, a study that we have already published (Mantovani \& Bartolotta, 2016). The Liceo was founded in 1864 but its history is older and dates back to the late eighteenth century when the ancient Regia Accademia "Ferdinando IV" (later known as Academy of Studies) was reopened to studies in Caltagirone. Our interest in the history of this Academy started when we discovered that the historical collection preserved an important unit of scientific instruments, bought in Paris in the years 1844-1846 from the French instrument maker Louis-Joseph Deleuil (1795-1862). This discovery inspired us to reconstruct the history of the R. Academy of Studies in order to identify the internal organization of its studies. In particular, our main aim was to identify the origins of the experimental physics in the Academy. As part of this latest research we came across the personality of Giovanni Silio Borremans who inaugurated the chair of experimental physics in 1775 and kept it for over fifty years, retiring only in 1826 .

\section{The Jesuits and the Tradition of "Good Studies" in Caltagirone}

In 1570, on the initiative of the senate of Caltagirone a Jesuit boarding school, with the aim of educating the youth ${ }^{1}$, was created.

The aforementioned school, under the obligations of the "Ratio Studiorum", was structured in two cycles of studies, the second of which, also known as "General Study", gave to the student the opportunity to obtain respectively the baccalaureate, the diploma and the doctorate. In 1622, at the Jesuit Lyceo, the "Studia Superiora" were instituted, thanks to a new initiative subsidized by the municipal council of Caltagirone and granted by the king of Spain, Felipe IV, and the boarding school was promoted to University of Studies.

The Lyceo thus came up as a peripheral university department since the attendance of the classes, certified by the dean and the senate of Caltagirone, gave the students the "license of candidacy for doctoral degrees", that is, a certificate of qualification which allowed the possibility to obtain the doctoral degree at the universities of the kingdom.

In 1628 the Jesuits obtained the addition of two new courses of study, the theological and the philosophical one (Taranto Rosso, 1857: p. 65). It is very likely

\footnotetext{
${ }^{1}$ As soon as it was established, the Jesuits obtained an annual allowance of 780 ducats from the senate (Taranto Rosso, 1857: p. 65). To boarding school in Caltagirone was the seventh oldest among those founded by the Jesuits in Sicily, only those of Messina, Palermo, Monreale, Siracusa, Bivona and Catania pre-existed (Narbone, 1851: p. 82, Vol. II).
} 
that the teaching of physical sciences in Caltagirone began in the philosophical course, however, no documentation has emerged.

In 1767 the Jesuits were expelled from Sicily and, in 1768, all their goods, including Caltagirone's boarding school ${ }^{2}$, were confiscated by the "Regio Erario".

\section{The Academy of Studies}

After the Jesuits were expelled, for Ferdinand IV $s$ will, a new project to regulate education, was developed by the bourbon government.

There was the creation of new boarding schools called "Academies of Studies", some of which were provided with university ${ }^{3}$ courses, held both by ecclesiastical and laic professors.

Thus, in 1775, the renewed boarding school in Caltagirone was called "Ferdinand IV Royal Academy", which will be known in the future as R. Academy of Studies (Figure 1 \& Figure 2).

As we will see, this important institution has benefited from subsidies by the city senate for more than eighty years.

Since the beginning, even with economic difficulties, the Jesuit boarding school was able to maintain the capacity to award diplomas and academic grades but, since 1825, the teaching rules have changed. In that year, a plan to reform the studies at all the boarding schools and the academies of the island was elaborated by the "Public Instruction and Education's Commission" in Palermo.

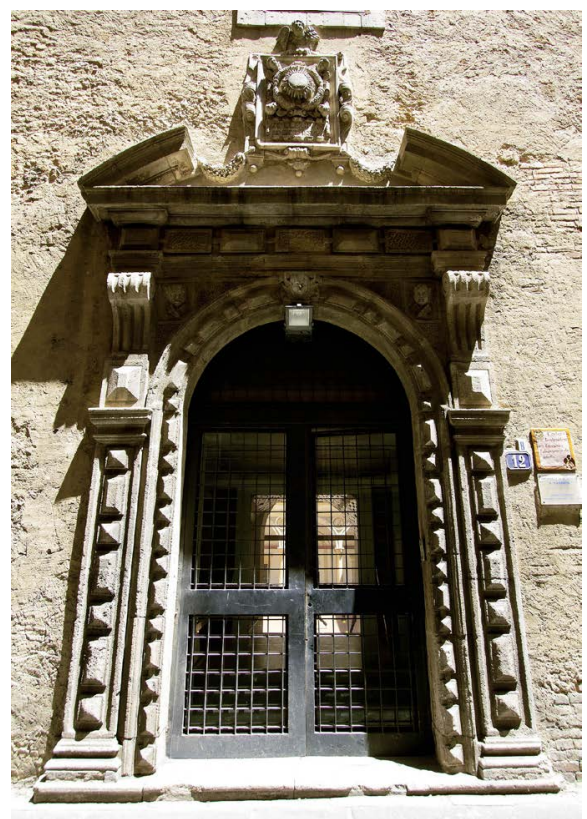

Figure 1. Main entrance of the former Jesuits' convent, ancient seat of the R. Academy of Studies, currently home of the "Alessio Narbone" Comprehensive State Institute of Caltagirone.

${ }^{2}$ In Sicily 29 boarding schools were closed, some of them, as those of Caltagirone, Palermo, Messina, Piazza Armerina, Siracusa, Trapani had academic privileges (Villari, 1980: p. 36).

${ }^{3}$ All the six boarding schools cited in the previous note obtained the antique privileges back and the "Status" of University of Studies. Only the new Acireale's boarding school was added to them.

${ }^{4}$ The Royal decree for creation dates June 12, 1775 (Narbone \& Taranto Rosso, 1871: p. 53). 


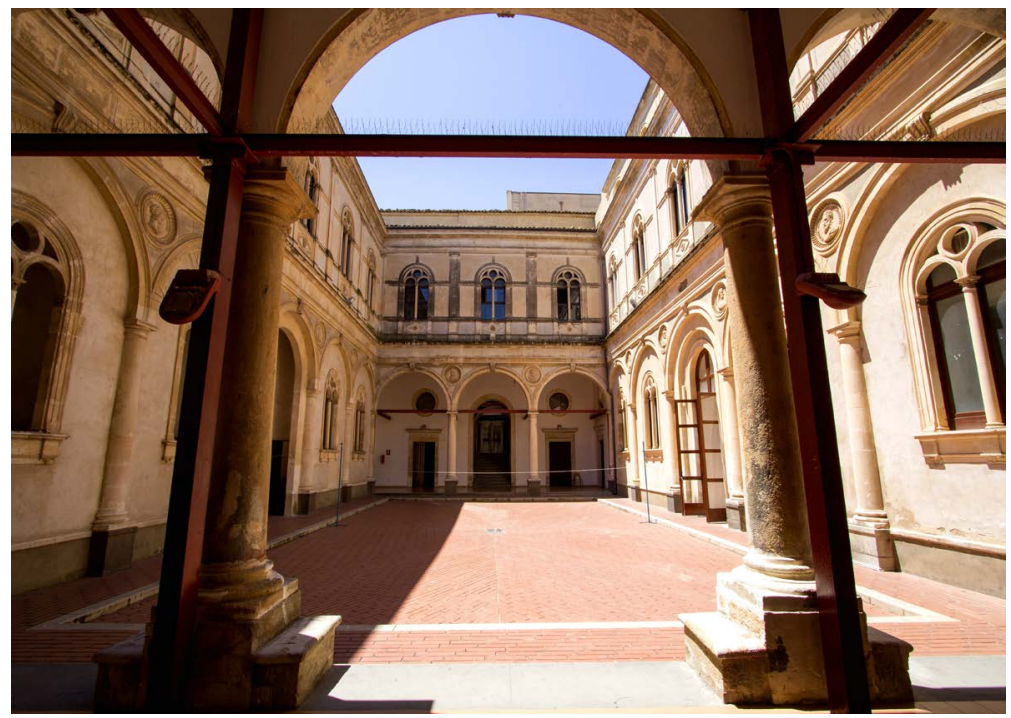

Figure 2. The Jesuits' convent closter, ancient seat of the R. Academy of Studies in Caltagirone.

The reform of the Academies of Siracusa, Trapani, Caltagirone, Piazza Armerina and Acireale primed at the suppression of some disciplines and the separation in individual teaching of these subjects: "physics, arithmetic with elements of algebra and geometry", "philosophy, algebra and trigonometry", "oratory and rhetoric" (Taranto Rosso, 1857: p. 88; Crimi, 1981: p. 92). The only structures allowed to confer the doctoral grades became the Universities of Palermo and Catania (Villari, 1980: pp. 41-42) and after fifty years of honourable service, in the field of higher education, the ancient R. Academy of Studies in Caltagirone lost the "Status" of provincial university and was transformed into a secondary school course, preparatory to university studies in the human and scientific fields. It maintained the same "Status" until 1858 when, at the request of the senate of Caltagirone, approved by King Ferdinand II, the Royal Academy was transformed into a new high school, that would have had once again the possibility to award the licence to academic grades for any university of the kingdom. It was called "Liceo Ferdinando" and it was dedicated to King Ferdinand II. The new high school remained active until 1862, when it was definitively suppressed by the Casati law (1859). Going back to 1775, the year of its establishment, the Academy was provided with a new "Studium" and two new teachings were instituted: "Logic and Metaphysics" and "Physics and Sublime Calculus" (Taranto Rosso, 1841: p. 159; Taranto Rosso, 1857: p. 87, notes 73). The Logic and Metaphysics' chair was assigned to religious Giuseppe Vinciguerra (Narbone \& Taranto Rosso, 1871: p. 95), whereas the one of "Physics and Sublime Calculus" was inaugurated by Giovanni Silio Borremans a nineteen years old promising teacher, from Palermo.

\section{Short Biographical Notes about Giovanni Silio}

About this talented scholar, not mentioned in the most recent historical repertories 
of the sector ${ }^{5}$, we have little biographical information. We know about his eulogy, uttered by his friend, the baron Camemi Martino Caldarera (1772-1857), but no trace of the written text has been found. The only information found comes from some manuscript ${ }^{6}$ documents and from a printed note written in 1841 by his most illustrious student and successor to his teaching post, Professor Emmanuello ${ }^{7}$ Taranto Rosso ${ }^{8}$ (Taranto Rosso, 1841: pp. 158-162). Sixteen years later, after that note, Taranto will write these short lines in memory of his beloved teacher:

"Giovanni Silio, brother of the conspicuous Michele and Guglielmo, my predecessor, put the vastness and profoundness of his philosophical and mathematical studies together. A person of rare morality and kindness and a good writer in prose and in poetry both in the Latin and in the Italian language. It is said that he has aroused the vagueness of physical sciences and conspired to forn the culture of amusing letters, during half century, that he spent teaching (Taranto Rosso, 1857: p. 88).

Born in Palermo in 1756 to Maria ${ }^{9}$ Borremans, Giovanni had four brothers Salvatore, Francesco, Michele e Guglielmo. Among these brothers only Michele and Guglielmo distinguished themselves in their professions ${ }^{10}$ (Figure 3). During his youth, Giovanni studied in Palermo at the Jesuits archiepiscopal seminary having as his guide, his older brother, Michele, and as schoolmates Gaetano Filangeri and Rosario Gregorio ${ }^{11}$. By his brothers' will, he initially devoted himself to the studies of law but, realized a certain aversion to the subject, he directed himself to the study of physics. His brother, Guglielmo Silio Borremans, who will die in Napoli in 1794, took up the mathematician's career instead, becoming professor at the "Royal Academy" of Trapani, then at the "Nunziatella's Royal Military Academy" (1787) in Naples. Guglielmo wrote about the living forces, studied ballistics and projectiles' movement. Domenico Scinà, a physicist

\footnotetext{
${ }^{5}$ His name was not pointed out by Scorsone A. (1987), nor by Allotta M. P., Di Maio F., Romano T. (2007).

${ }^{6}$ Some information was found studying the 26 letters addressed to Giovanni Silio between 1785 and 1826 (see fund "Manoscritti Silio Guglielmo Corrispondenza varia", manuscripts room, Municipal Library E. Taranto, Caltagirone). Also very useful was the founding of a manuscript notes by scientist Emanuele Taranto Rosso containing short but significant biographical information about Silio. This dates about the fourth decade of XIX century.

${ }^{7}$ This is the original name used in signing by Taranto Rosso. However, in accordance with the following literature, from now on we will use the caption "Emanuele".

${ }^{8}$ Don Luigi Sturzo's great-uncle, gifted with ample erudition with strong religious interests, Taranto Rosso (1801-1887) was a scientist, benefactor, historian, person of letters, politician among the most influential and representative of the city of Caltagirone during the nineteen century.

${ }^{9}$ The information is deduced from Taranto Rosso (1841: p. 158). A manuscript notes that tells about Silio's death, indicate instead "Anna" as the mother's name (see fund "Randazzini V", "Calatinian University”, c. 111, shelf XII, manuscripts room, Municipal Library E. Taranto, Caltagirone). Finally, in some letters the name "Rosalia" is indicated as his mother's name.

${ }^{10}$ Michele was, at first lecturer of philosophy at the Archibiscopal Seminary of Palermo, then, summoned by Pio VI who greatly esteemed him, became general auditor in Rome; Guglielmo, as we will see, distinguished himself as a good mathematician.

${ }^{11}$ Illustrious scholar and historian of Sicilian events, canon Gregorio became in 1789 professor of Sicilian public law at the Academy of Palermo and, in 1797, royal historiographer.
} 


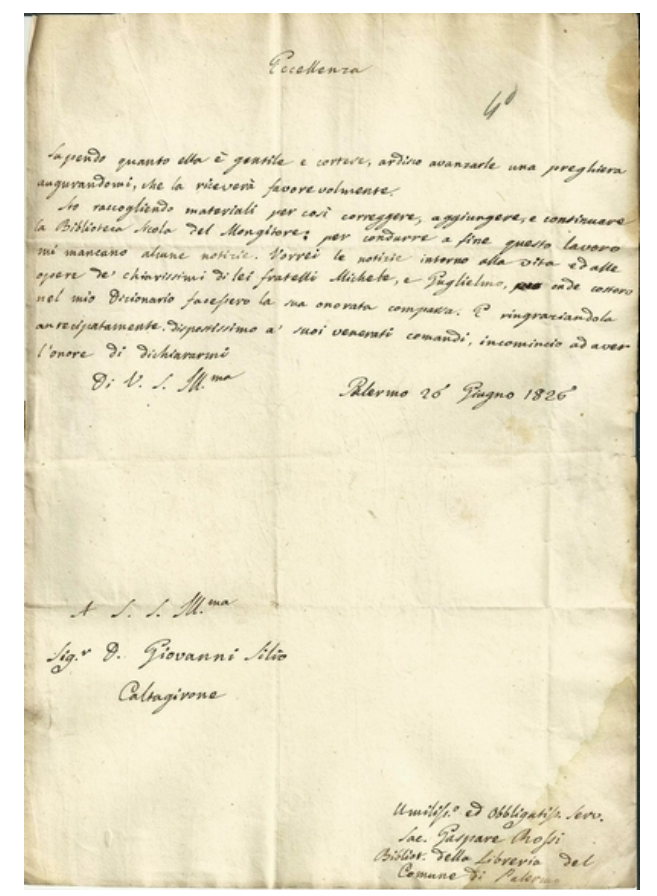

Figure 3. Letter written in 1826 by Gaspare Rossi, librarian of the Municipality of Palermo and addressed to Giovanni Silio. In this letter he asks information about Michele and Guglielmo, Giovanni's brothers, in order to include their names in a biographical dictionary. By Courtesy of Municipal Library E. Taranto in Caltagirone.

and historian of Sicily, outlining his scientific figure, highlighted two contributions (Scinà, 1859: pp. 340-342). In the first writing Scinà states that Guglielmo went against the teaching of the religious and mathematician Giovanni Battista Nicolai (1726-1793), of the University of Palermo, who insisted on teaching new analysis' rules by considering as false those established up until that time (Silio Borremans, 1787). As regards the second contribution Scinà highlights that Guglielmo Silio wrote a curious essay about the influence of analysis on political and economic sciences, applied to contraband, in which he demonstrated, using algebra, how the government should prorate punishments to the different kinds of contrabands (Silio Borremans, 1792). After the Jesuits were expelled, the need to reopen the suppressed Jesuit schools was perceived. Due to the existence of numerous vacant tenures, the "Public Education" in Palermo announced various public exams and within them the one of Physics and Mathematics, to the benefit of the newly founded "Royal Academy of Studies" in Caltagirone. Having completed and won the public exams, Giovanni Silio obtained from the government the assignment of reopening the new school of Physics and Superior or Sublime Calculus in Caltagirone.

The new courses started in November 1775. Thus Silio began his teaching of Physics and Sublime Calculus ${ }^{12}$ with a good annual salary of 180 ducats. After a few years, due to problems with the state budget, his annual salary was decreased

${ }^{12}$ As already mentioned, in 1825 the teaching of physics became an individual post (Taranto Rosso, 1857: p. 88). 
to 108 ducats. Despite the pay cut, he continued to teach with great dedication and proficiency, as he always did with perseverance during his fervid educational activity at the Academy that lasted for more than fifty years. During that time, he gave various academic speeches, for example, in July 1778 "On the origin of thunders and lightning" and in August 1783 "On astrology". During his early years of teaching Silio was a victim of a serious event, that dates some years after 1782 and was narrated by Taranto $^{13}$ (Taranto Rosso, 1841: p. 159), whose information and details, unfortunately, are almost totally unknown. According to the concise report of his biographer, Silio, had always carried out his teaching with a modern approach against the peripatetic ideas, at that time largely dominant. He was at first discredited for his actions, then defamed and called back in Palermo in front of the "Supreme Deputation of Public Education" and it was presided by Prince of Torremuzza. The Commission, acknowledging the falsity of the accusations, not only recognised the young professor as a good teacher, but also offered him the opportunity to get the physics-mathematic tenure at the University of Palermo, then still vacant. Silio renounced preferring to continue his teaching in Caltagirone, because he loved the city. In 1794, being in Naples, after his brother's death ${ }^{14}$, he participated in a competitive exam for the vacant general physics' position at the University of Catania, passing and winning it. However, the government denied him the position, assigning him only an annual income of 36 onzas, state money, though this would add up to the salary of 60 onzas (Taranto Rosso, 1841: p. 160).

In 1804, with the approval seal of the senate, Silio became a citizen of Caltagirone for his scientific and literary credits. He taught at the academy until February 1826, after then he asked to be relieved from his position in order to work full time on a course of transcendental physics ${ }^{15}$ (Taranto Rosso, 1841: p. 161) about which, unfortunately, we didn't find any information among his manuscripts.

On June 23, 1826, he was granted the permission to retire and his exit salary corresponded to 5626 annual onzas, pointing out that 5202 would be deposited by the municipality and 424 by Palermo's Royal University of Studies ${ }^{16}$. Three days later the chair of Physics left vacant by Silio was put out to public contest by the Municipality of Caltagirone (Figure 4). During the last years of his life he began composing a written work, "The principles of physics" and, as Taranto

\footnotetext{
${ }^{13}$ In the account Taranto mentions that the episode took place a few years after the abolition of the inquisition court in Sicily, wanted by viceroy Domenico Caracciolo. The abolition occurred March 27, 1782, by decree of Ferdinand of Spain.

${ }^{14}$ Among the letters present in the manuscripts it turns out that Guglielmo Silio died in May 1794 and that Giovanni stayed in Naples between May and August.

${ }^{15}$ Taranto Rosso informs that Silio, who was formed as a Leibnitzian, loved to call that course "metaphysics of physics". According to Silio physics and metaphysics were not antithetical but had a certain continuity. The physical world was not to be explained only with the Cartesian ideas of res-extensa and movement but also with the idea of force yet to be intended both in physical and spiritual sense.

${ }^{16}$ Manuscript letter of June 23, 1826 (see Fund "Randazzini V", “The University of Caltagirone", c. 108, shelf XII, manuscripts room, Municipal Library E. Taranto, Caltagirone).
} 


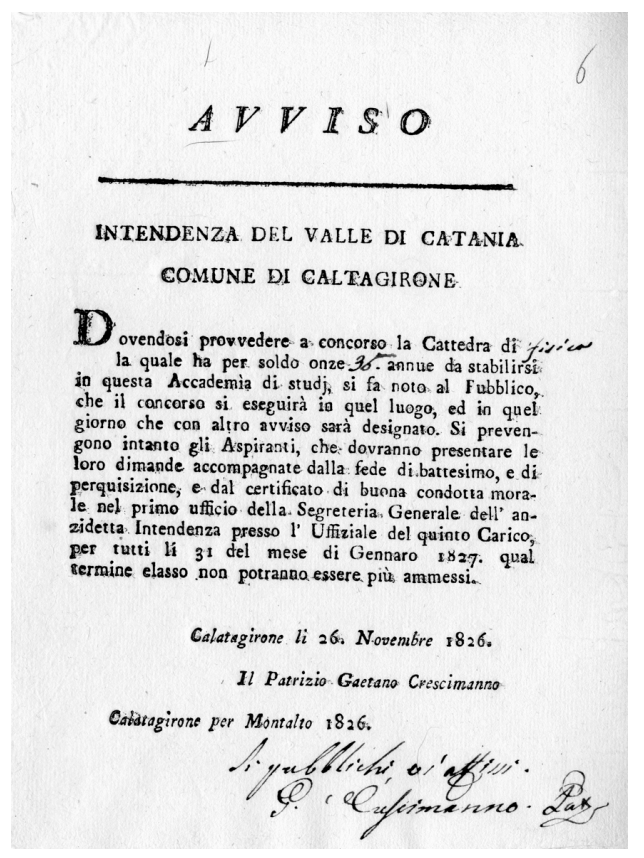

Figure 4. Public notice concerning the Contest for the Chair of Physics at the Academy of Studies of Caltagirone, dated 26 November 1826. By Courtesy of Municipal Library E. Taranto in Caltagirone.

informs, "the first sheet of paper was under the printing press" when Silio died on April 19, $1830^{17}$.

According to some sources, he lived his whole life without fixed abode and was claimed by various noble families from Caltagirone, which hosted him ${ }^{18}$.

Learned and of extended erudition, during his 51 years of teaching, Silio formed very many pupils of all social classes, some of which would then distinguish themselves in their professions, such as Baron Cameni or the successor to his post and his main biographer, Emanuele Taranto Rosso.

In his personal library he had hundreds of books on various subjects that he would have liked to donate to Public Library in Caltagirone, which actually didn't happen because he didn't leave any will. In addition to physical and mathematical disciplines he also had an interest in economics ${ }^{19}$, he knew Latin and Greek very well ${ }^{17}$ His memory was solemnly honoured in November 1835 by the "Talatinian Arcads" in the "great room of public wisemen" of the R. Academy of Studies on occasion of the inauguration of the school year at the presence of the bishop, the administrative authorities and "the most learned and respectable people of the city". The eulogy was delivered by Baron Camemi, the keynote address by Carlo Chiarandà, the introduction by Prof. Federico Ardilio and the offering by Emanuele Taranto Rosso. Last, some poetical compositions followed (see "Journal for Caltagirone's R. Academy of Studies, starting from 1831 under the management of Mr Cav. D. Emanuello Taranto Rosso", ms., shelf XIV, manuscripts room, Municipal Library E. Taranto, Caltagirone). From the consulted manuscripts it emerges that on that occasion it was also drafted the "Proposal and subscription for a Mausoleum dedicated to Prof. of Physics and Mathematics Silio dr. Giovanni".

${ }^{18}$ However, according to a Taranto Rosso's manuscript, "he lived his entire life" with the Cavalieri family (see "Giovanni Silio's biographical notes" (incomplete notes), ms. sheet, shelf XIV, Municipal Library E. Taranto, Caltagirone).

${ }^{19} \mathrm{He}$ wrote various economics essays for Cav. Giacomo M. Aprile Benzo. From 1812 to 1814, the latter was delegate for the city of Caltagirone at the Chamber of the Municipalities and, from 1829, member of the Deputation of Caltagirone's R. Academy of Studies. 
and loved to compose poetry ${ }^{20}$. From 1824 he was correspondent member of the Gioenia Academy of Natural Sciences in Catania (Figure 5).

\section{Silio and the Aerostats}

The "corpus" of Silio's writings is completely hand written. There is only one exception of a printed work, the "Theory on aerostats direction"21 (Silio Borremans, 1790), posthumous work of the end of the 1700s, published in 1841, thanks to his biographer Emanuele Taranto Rosso ${ }^{22}$. In an introduction to the article, the latter informs that the autograph manuscript, without illustrations and in a precarious state of preservation, had been held by his student and friend Baron Camemi, after Silio's death. The baron reconsidered it when he knew about the invention made by the mechanic and aeronaut Muzio Muzzi from Bologna, who in 1838 had built a particular model of air balloon, with a lenticular form, called "rettiremiga" airship (Figure 6). In addition to it, in the same

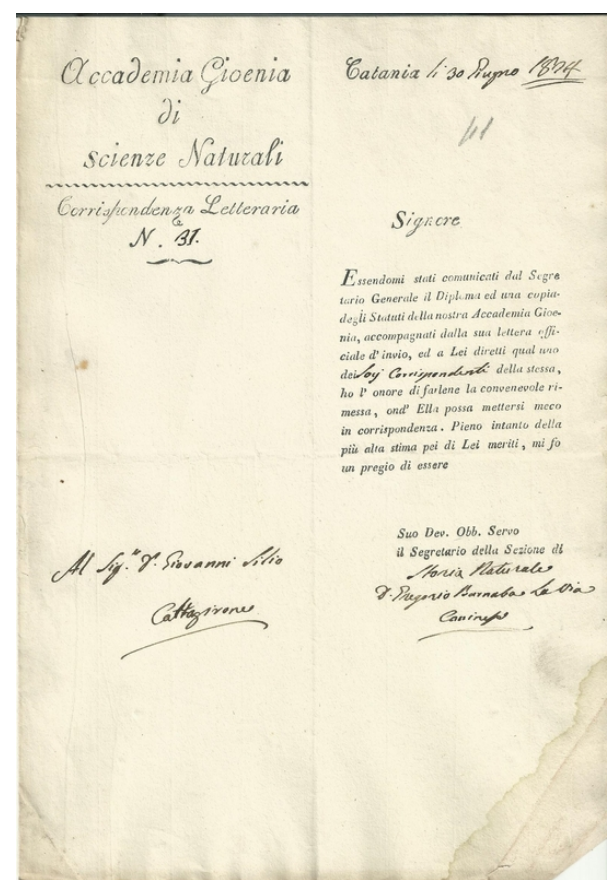

Figure 5. Letter written by the Secretary of the "Gioenia" Academy of Catania in 1824 and addressed to Giovanni Silio. In this letter Silio was appointed "corresponding member” of the Academy. By Courtesy of Municipal Library E. Taranto in Caltagirone.

\footnotetext{
${ }^{20}$ Among Silio's manuscripts noted down by Taranto there's also a booklet with a collection of 38 sonnets (see "Poems by Giovanni Silio, Public Professor of Physics and Sublime Calculus at Caltagirone's R. Academy of Studies", ms., shelf XIV, manuscripts room, Municipal Library E. Taranto, Caltagirone). In the first page, next to the first sonnet, this note by Taranto Rosso can be read: "This and the following sonnets were part of a collection of poems belonging to the author that went lost". In the collection there are the following sonnets of a certain interest: "On Physics, 1809"; "On the usefulness of sciences, may 1809"; "On Physics"; "For the Academy re-establishment".

${ }^{21}$ This memory in Dollo's work (1979: p. 227, note 65) is erroneously attributed to Guglielmo Silio.

${ }^{22} \mathrm{As}$ it is read in other sources (for example in Mira, 1881: p. 367, Vol II), it wasn't Baron Camemi who took initiative for publishing Silio's posthumous manuscript, but Taranto, as it emerges form a letter dated May 7, 1843 and sent to Taranto by Barbaro Maggiore (see fund "Taranto's correspondence", manuscripts room, Municipal Library E. Taranto, Caltagirone).
} 


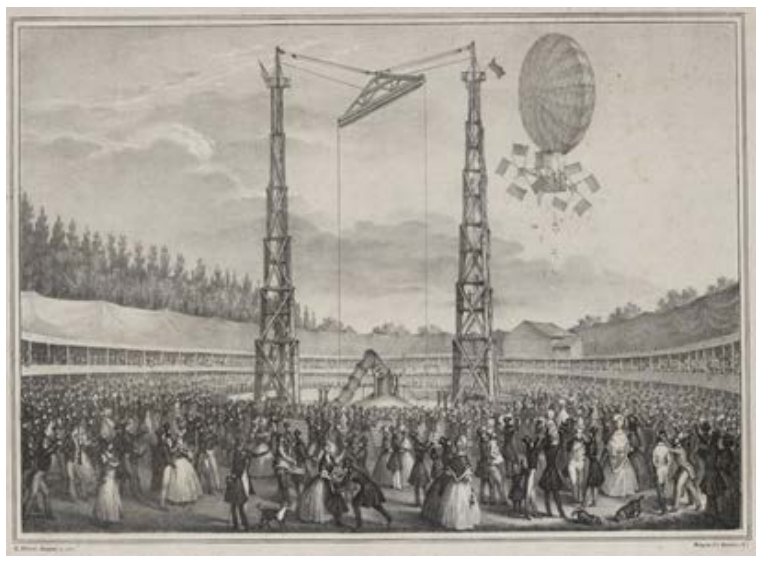

Figure 6. Lithograph showing the flight performed in Bologna in 1838 by the Italian aeronaut Muzio Muzzi through the Airship invented by himself and called "Aeronave Rettiremiga". This hot-air balloon could be orientated and guided by a complex system of wheels and sails. Furthermore the flame was powered by an alcohol lamp having cardanic suspension and equipped with Davy-type wire mesh.

note, Taranto affirmed:

"The author [Silio] dictated these thoughts few years after air balloons invention, around 1790, at the same time when thanks to illustrious P. Di Clasi, he worked on the new collection of Sicilian pamphlets, and would have liked to include them, but something wrong impeded him from doing it'" (Silio Borremans, 1790: p. 162).

In fact, it seems that Silio had sent his work to the priest Salvatore Di Blasi, founder and editor of the "New collection of Sicilian Authors pamphlets" 23 , from 1788 to 1796 , but he didn't receive any encouraging answer from him because " $I$ didn't have any other encouragement, apart from a simple approval'. But why was Silio interested in the physics of the aerostats? The history and events of the rettiremigan airship lead us to the end of the 1700s and the numerous attempts, proposal and projects proposed after Montgolfier, to solve the long-standing problem of aerostats' steering. In fact the balloons were left at the mercy of the atmospheric currents, except for the stages of rising and descent, and without any solution to this pivotal problem, the bright invention risked to remain an end in itself for its undeniable scarce usefulness. Since 1783 the attempts were numerous and lasted throughout the 1800s. Probably Silio was stricken by the very first ascensions in Sicily. Thanks to the gazettes of the time the news of the Montgolfier brothers' ascension arrived also in Sicily, particularly in Palermo. A French book (Heubach, 1784), printed in Losanna and featured with some illustrations fed the anxious curiosity of the people from Palermo about the new invention. Various attempts to reproduce the invention, described by the French newspapers, were made by the engineers and professors of the university of Palermo but the "taffetevole" balloon, as the chronicles of the time called it, was

\footnotetext{
${ }^{23}$ In 1792, in this same pamphlet, one of Guglielmo Silio's most important work (previously cited) was published, the hefty "Essay about the influence of analysis on political and economic sciences applied to Contrabands" (Silio Borremans, 1792).
} 
never able to take off (Scinà, 1827: p. 68).

The venture, thanks to the correct calculation of the weight and the balloon's structures, was instead accomplished on March 14, 1784 by Prince of Pietraperzia, D. Ercole Michele Branciforti (Cannella, 1784), who later will become Prince of Butera. But almost certainly the venture that mostly inspired Silio's interest was the one accomplished in 1790 by an intrepid aerostat from Lucca, Vincenzo Lunardi, who had already made thirteen ascensions in Europe (Figure 7). After an unsuccessful attempt, Lunardi, on July 31, 1790, ascended in the sky of Palermo with his aerostatic balloon returning after a flight of almost two hours with a dramatic landing (Pitrè, 1904: pp. 42-43, Vol. II). The compatibility of time between Silio's work and Lunardi's ascension and the epilogue of the landing at about thirty kilometres from the departure point due to the aeronaut's substantial inability to steer flight, could corroborate the hypothesis of a tight relationship between the two events. Unfortunately, Silio's work lacks explicatory illustrations and as a consequence the airship model turns out to be unclear, even to a careful reading. From a methodological standpoint, he combined principles of physics and mathematics with some analogical models, deduced from everyday experience. The balloon descibed was probably the typical hot-air even if the burner is not described. The new elements introduced by Silio was the shuttle that could be piloted through some hand-driven devices basically deduced by the analogical models of a rowing boat and fishes movement. Fishes move thanks to the tail's continuous movement. Silio added to the shuttle's stern a tail-like unit made half of wood and half of "leather", filled up with hydrogen or "inflammable air" as it was called at the time and that in some way could operate as a wheel. He then added two special oars made half of wood and half of leather

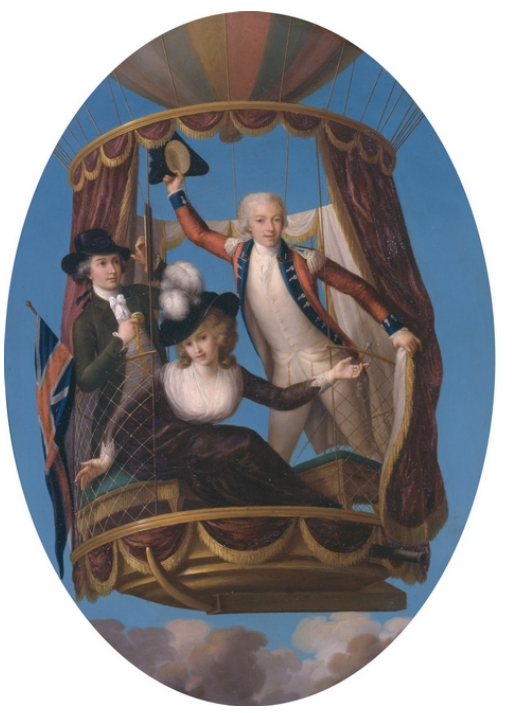

Figure 7. Oil on copperplate (Ca. 1785) showing the ascent of a hot-air balloon in London in 1785. This flight was performed by the pioneering Italian aeronaut Vincenzo Lunardi (1759-1839), accompanied by his assistant, the artilleryman George Biggin (c. 1760-1803), and by the famous actress Letitia Ann Sage (1773-1817), the first British woman to make a balloon flight (Yale Center for British Art, Paul Mellon Collection). 
bags filled up with hydrogen to the sides of the shuttle. With regard to the theory of shuttle's movement through atmospheric currents, Silio opted for an analogical scheme similar to the pneumatic pump, for a possible explanation. According to him, the viscous air currents produced inside the two whirlwind units of a pneumatic pump, produced the same turbulence conditions underwent by the shuttle. This and also the others ideas produced by Silio, clearly outline the heuristic models he used to design the new hot-air balloon. However, as far as the rediscovered manuscripts are concerned, it doesn't turn out that he tested his project with any real attempt.

\section{The Rediscovered Manuscripts}

Silio didn't like publishing his researches ${ }^{24}$ very much. Fortunately, however, his manuscripts were preserved, by his successor to the chair of physics, Taranto Rosso (Figure 8).

A careful and long-lasting archive work has allowed us to identify a big part of those manuscripts ${ }^{25}$, which also include a limited number of letters (see note 6) coming from his personal correspondence ${ }^{26}$. They deal with a wide spectrum of scientific problems, but we can also find some poems and philosophical works. Among the scientific manuscripts works of geometry, mathematics and astronomy stand out. Some of these works have come to us in the form of copies dictated by Silio to his most famous pupil, Emanuele Taranto Rosso. It is the case, for example, of the "Treatise of composed equations by the method of Sir D." Giovanni Silio, Professor of Physics, and Sublime Calculus at the Royal Academy

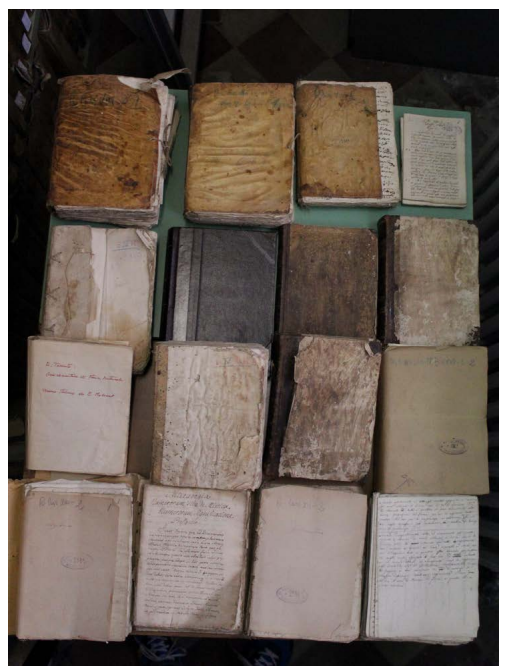

Figure 8. Some handwritten works that belonged to G. Silio's pupils and kept at the $E$. Taranto library in Caltagirone. By Courtesy of Municipal Library E. Taranto in Caltagirone. ${ }^{24} \mathrm{He}$ loved to say that the students he had formed were his works or his "speaking books" (Taranto Rosso, 1841: p. 161). As we will see, the Municipal Library of Caltagirone E. Taranto preserves a good number of manuscript works that belonged to his students.

${ }^{25} \mathrm{~A}$ limited number of them were also reported in the bibliographic repertoire of Narbone and Taranto Rosso in Caltagirone (1871: pp. 103-105, p. 111, p. 167).

${ }^{26}$ The whole Silian corpus of manuscripts is gathered at the E. Taranto Municipal Library of Caltagirone, shelves XIII, XIV, VII. 
of Studies in Caltagirone, 1819-20"27 (Figure 9). However the most significant manuscripts are about the teaching of physics thanks to the presence of manuscripts in the form of notes, lecture and essays, the latter largely incomplete or not found ${ }^{28}$.

From 1776 to 1805 as regard to the method adopted, Silio made use of dictations in "a refined Latin language" for his students and, after that period, he continued the dictation of his lessons in Italian (Taranto Rosso, 1841: p. 161; Narbone \& Taranto Rosso, 1871: p. 111). According to Taranto, Silio used to modify his manuscript work, course after course, in order to consider the changing and tumultuous progresses of the science in his time. Among the numerous manuscripts consulted, the only one that presents a certain completeness and coherence of exposition is the work "Institutiones Physicae Generalis et Particularis $^{29}$ (Figures 10-13). Reading the index, the work turns out to be divided into two parts philosophiae naturalis institutiones ${ }^{30}$, organised in twelve chapters $^{31}$, and Phisica Particularis ${ }^{32}$, organised in eighteen chapters ${ }^{33}$.

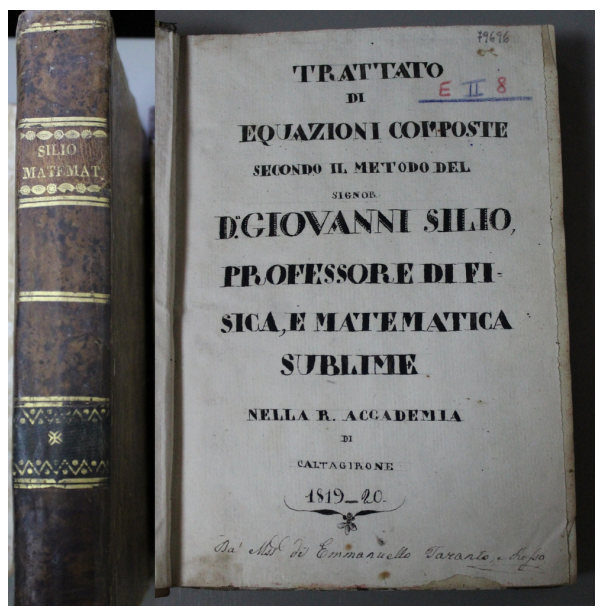

Figure 9. Frontispiece of the manuscript treatise of E. Taranto Rosso of the years 1819-1820 concerning the "compound equations" explained according to the method of prof. G. Silio. By Courtesy of Municipal Library E. Taranto in Caltagirone.

\footnotetext{
${ }^{27}$ In his personal library Taranto Rosso had also the following Silio's works, today unfortunately missing: Institutions of Analytical Mathematics, Treatise about Sphere and Astronomy (Narbone \& Taranto Rosso, 1871: p. 103, p. 105).

${ }^{28}$ Some of these come from Silio's work, others from his students' and particularly, as already mentioned, from Emanuele Taranto Rosso. Unfortunately, many of these manuscripts aren't signed and therefore they present attribution issues.

${ }^{29}$ This title, absent in the work, was recreated thanks to the testimony of Taranto Rosso (Narbone \& Taranto Rosso, 1871: p. 111). The reading of the index's topics confirms, substantially, the correctness of the title.

${ }^{30}$ Below this title it can be read "to Joanne Silio Cathedram moderante in R. Studiorum Academia Calatajerone" (see Shelf VII, manuscripts room, Municipal Library E. Taranto, Caltagirone).

${ }^{31}$ This part of Physica Generalis, of a more traditional sort, deals with the most common properties of bodies, motion, weight and gravitation.

${ }^{32}$ Physica Particularis developed thanks to the emergence, during the second half of the eighteen century, of new fields of research and essentially pursued an experimental approach to Nature.

${ }^{33}$ The topics treated concern machines, hydrostatics, capillarity, optics, atmospheric phenomenon and therefore meteorology, electricity, natural magnetism and galvanism. This last argument touches upon Volta's battery. This detail allow us to date the manuscript at the very beginning of the 1800 s.
} 


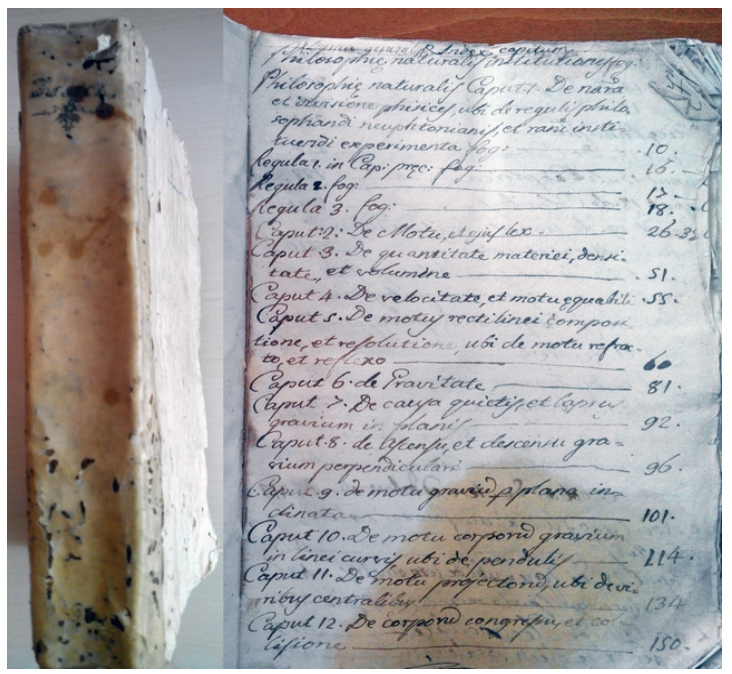

Figure 10. The "Institutiones Physicae Generalis et Particularis", an unsigned work, probably written by one of G. Silio's students. Book index. By Courtesy of Municipal Library E. Taranto in Caltagirone.

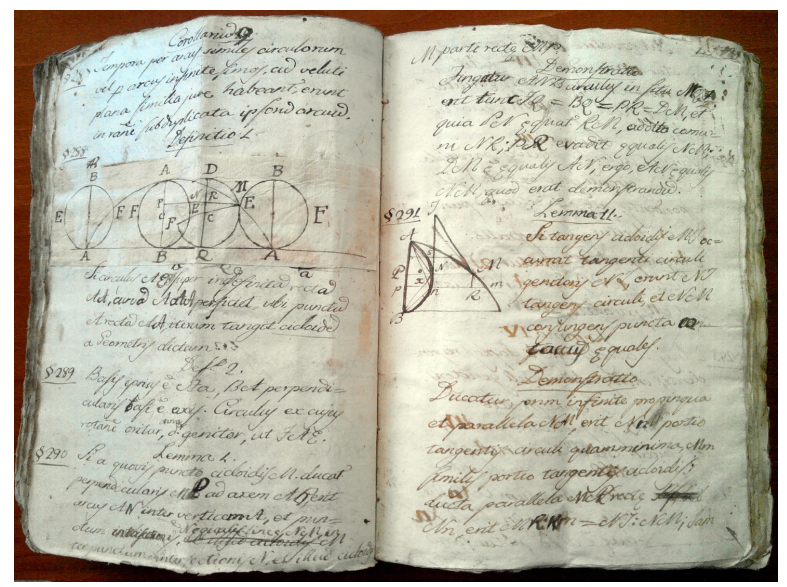

Figure 11. The "Institutiones Physicae Generalis et Particularis". Geometric study of the cycloid. By Courtesy of Municipal Library E. Taranto in Caltagirone.

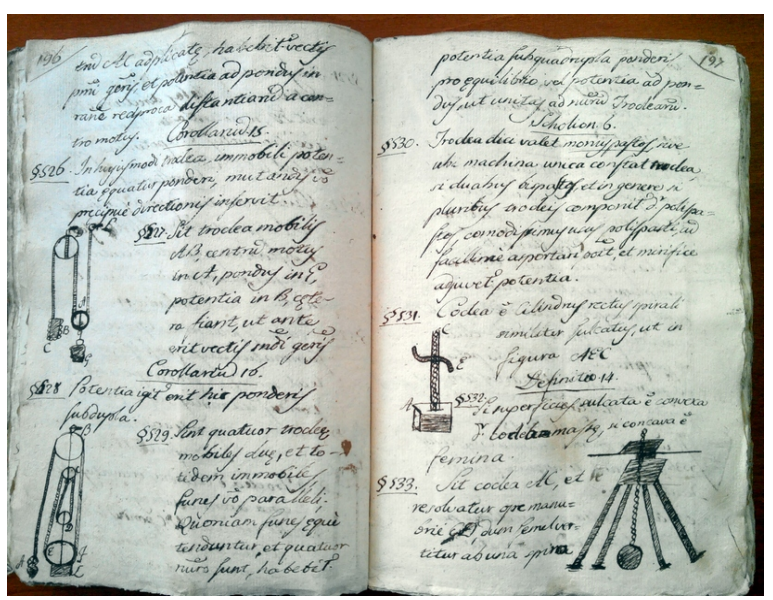

Figure 12. The "Institutiones Physicae Generalis et Particularis". Drawings of some mechanical devices. By Courtesy of Municipal Library E. Taranto in Caltagirone. 


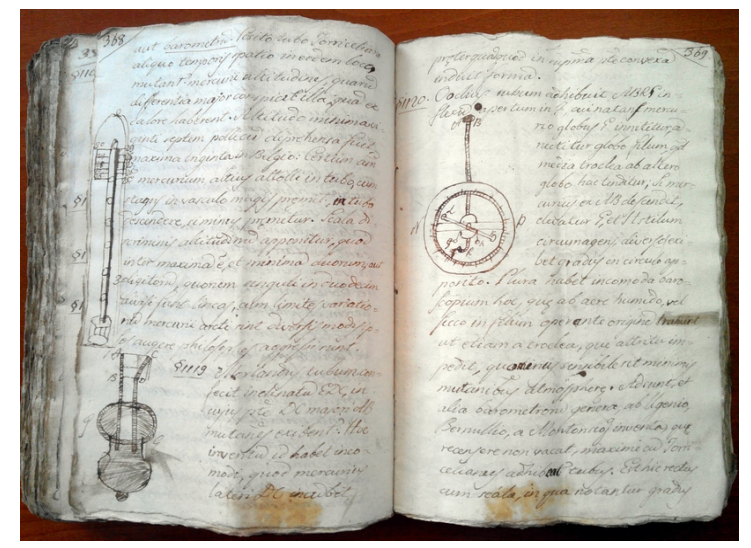

Figure 13. The "Institutiones Physicae Generalis et Particularis". Drawings of barometers and a hygrometer. By Courtesy of Municipal Library E. Taranto in Caltagirone.

Comparing the various manuscripts found we understand that the topics treated had to be part of a basic course of physics held by Silio between 1776 and 1805.

This certainty originates from the founding of many copies, often incomplete and written in different styles of the Institutiones Physicae, some of them ascribable to Silio ${ }^{34}$ himself, others transcribed by his pupils ${ }^{35}$. The work we consulted consists of about 600 pages and it is structured in definitions, theorems and corollaries according to the method of Newtonian philosophy. It limited, as Euclidean deductive rules used to do, the theory to propositions, but without help from geometry and mathematics.

In the first introductive chapter the nature and the subdivision of physics, the Newtonian rules in philosophy and the reason for setting up experiments are discussed.

In the "corpus" of Silio's manuscripts, written in Italian, numerous copies of his lessons of physics are also found. Among them a complete manuscript written in 1818 by one of his students ${ }^{36}$ (Figure 18) and a complete work in two volumes $^{37}$, dated 1819-1820, (Figure 19) written by his most famous pupil and successor, Emanuele Taranto Rosso stands out. This last work deserves a brief description. The first book is entitled "About Physics that is Natural Philosophy. Treatise on the method of sir D. ${ }^{n}$ Giovanni Silio, Professor of this science at the Royal Academy of Studies in Caltagirone. Written in Caltagirone by Emmanuele

\footnotetext{
${ }^{34}$ In a binder for manuscripts eight notebooks were found that, after a calligraphic comparison, are attributable to Silio. In fair copy, they are identical to the essay Institutiones Physicae. The binder also contains two notebooks signed by Silio relating to two Dissertatio on the measurement of forces and on gravitation, three notebooks dated 1794 on fluids and optics, and lastly six notebooks about astronomical themes (preface to astronomy, motion of planets, stars, comets) for a total of 260 pages (see shelf XIV, manuscripts room, Municipal Library E. Taranto, Caltagirone).

${ }^{35}$ Among the different copies consulted, just one turns out to be signed and dated. In the frontispiece it can be read "Ex meis manuscriptis D Joseph Strazzuso Ex Libris G. S. $D^{\text {ris }} D^{n}$ Josephi Strazzuso Anno Domini Millesimo octinaentesimo octavo" (Figures 14-17).

${ }^{36}$ The title of the work is "About physics, or Natural Phylosophy dictated in Caltagirone by $D^{n}$ Giovanni Silio in 1818". It is signed "S. M.", almost certainly one of his student initials.

${ }^{37}$ Shelf VII, manuscripts room, Municipal Library E. Taranto, Caltagirone.
} 


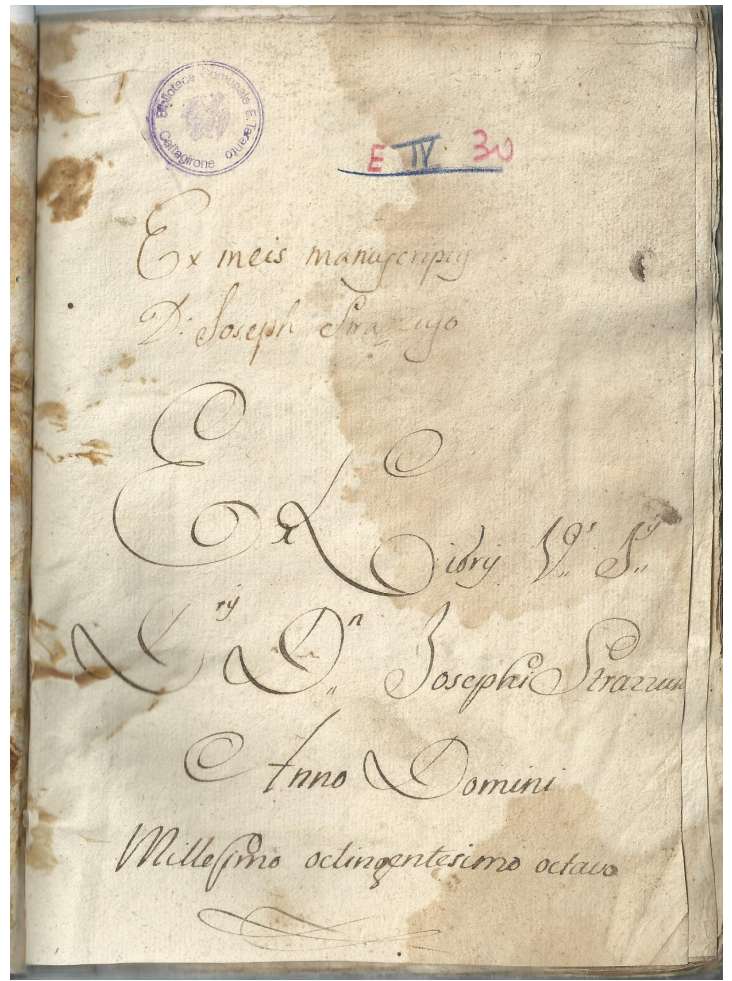

Figure 14. Frontispiece of the "Institutiones Physicae", a work transcribed in 1808 by "Strazzuso", one of G. Silio’s pupils. By Courtesy of Municipal Library E. Taranto in Caltagirone.

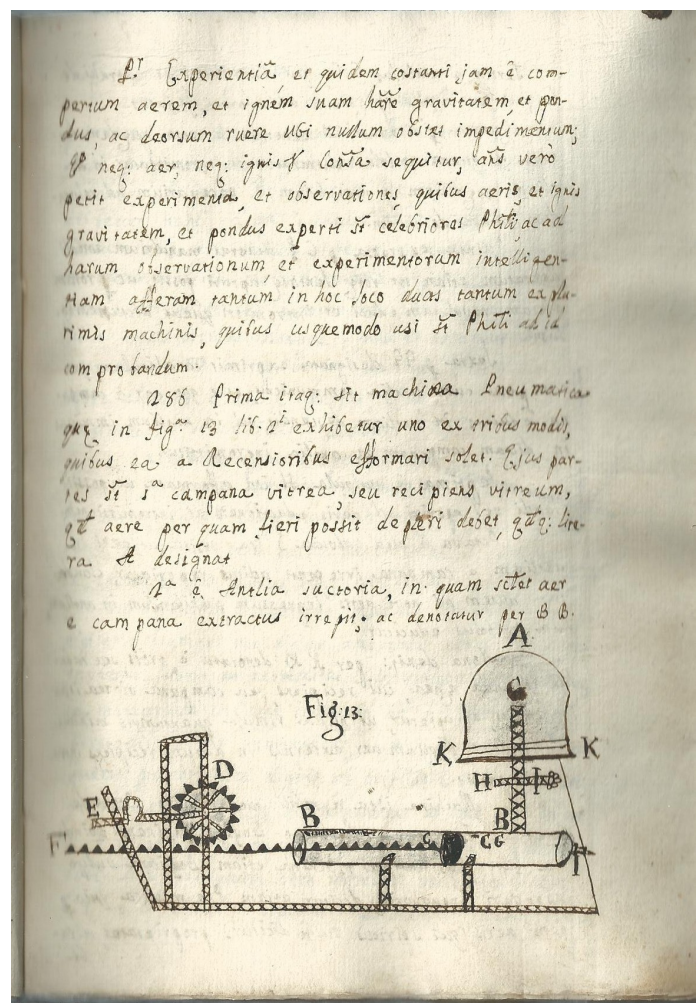

Figure 15. The "Institutiones Physicae" by Strazzuso, a pupil of Silio. Drawing of a pneumatic air pump. By Courtesy of Municipal Library E. Taranto in Caltagirone. 


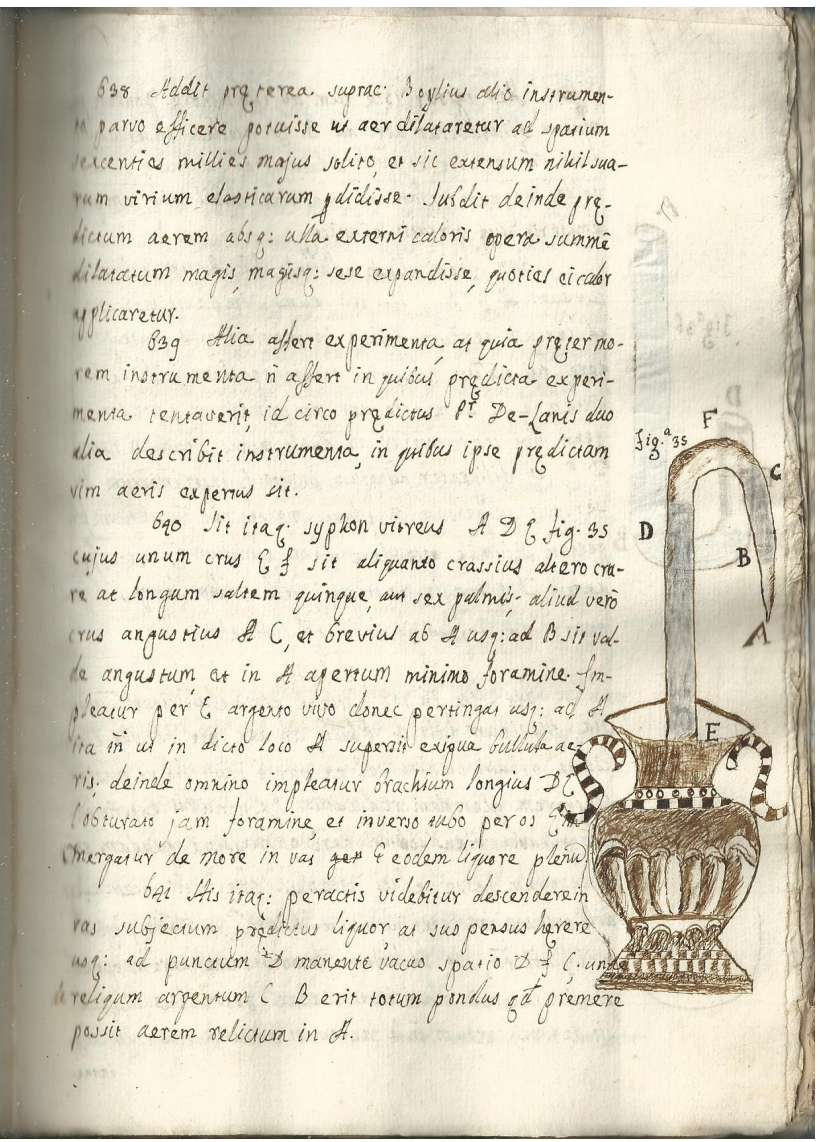

Figure 16. The "Institutiones Physicae" by Strazzuso, a pupil of Silio. Drawing of a Tantalus vessel. By Courtesy of Municipal Library E. Taranto in Caltagirone.

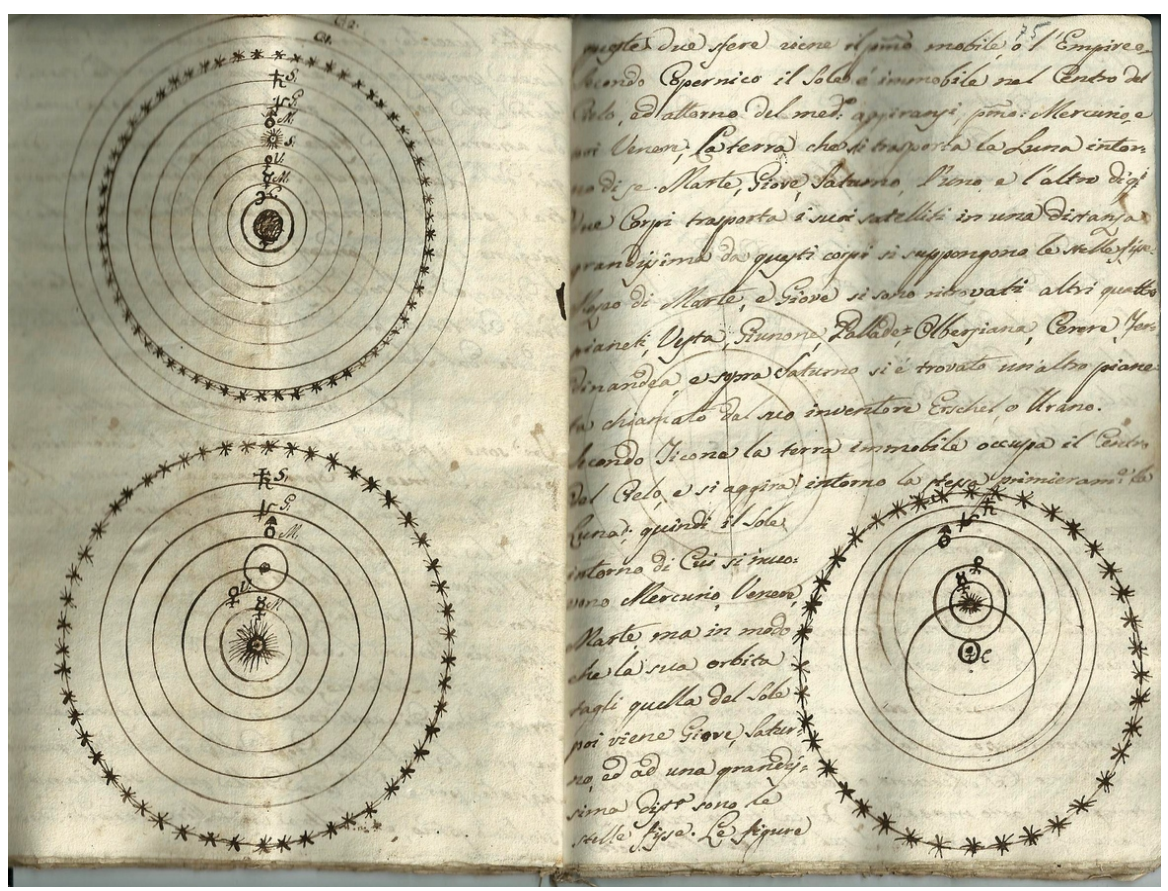

Figure 17. The "Institutiones Physicae" by Strazzuso, a pupil of Silio. Drawings of some astronomical systems. By Courtesy of Municipal Library E. Taranto in Caltagirone. 


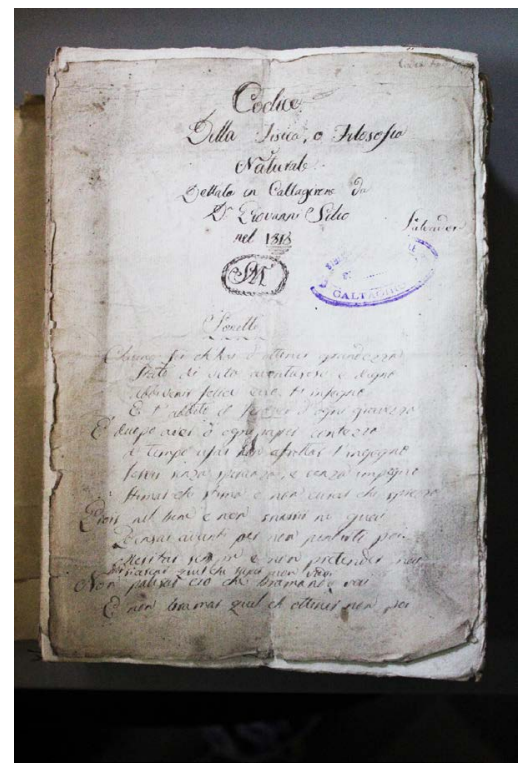

Figure 18. Frontispiece of Giovanni Silio's work entitled "Codex. Of Physics, or Natural Philosophy dictated in Caltagirone by Dn Giovanni Silio in 1818”. Copy transcribed by one of Silio's pupils, signed “S. M.”. By Courtesy of Municipal Library E. Taranto in Caltagirone.

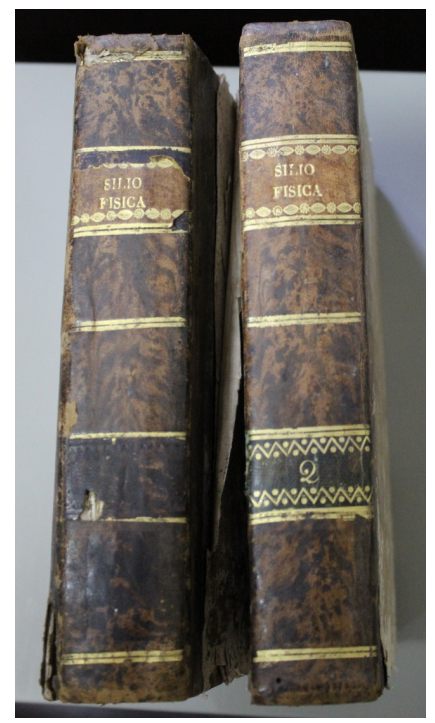

Figure 19. Complete manuscript treatise, in two volumes, of the lectures given by Giovanni Silio in the years 1819-1820, a work transcribed by E. Taranto Rosso. By Courtesy of Municipal Library E. Taranto in Caltagirone.

M. a Taranto Rosso, in the year 1819" (Figure 20). The work consists of about 480 pages. Its structure is still axiomatic and takes inspiration from the Newtonian $^{38}$ model of the Principia and "from the way of debating using induction, without which no progress could be made in Natural Philosophy" (Silio Borremans, 1819: p. 19). In the introduction the structure of natural philosophy is analytically defined, in its various meanings, as a didactic introduction to the ${ }^{38}$ Silio affirms: "In the definition of the causes of phenomenon, and of the properties of bodies, it helps to follow the rules of knight Isaac Newton." (Silio Borremans, 1819: p. 17). The author, then, continues by listing three rules of Newton. 


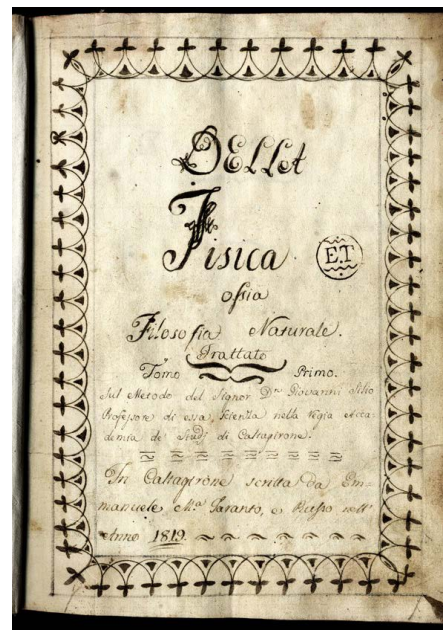

Figure 20. Manuscript frontispiece of Giovanni Silio's lecture course conducted in 1819 and transcribed by E. Taranto Rosso. By Courtesy of Municipal Library E. Taranto in Caltagirone.

study of the subject ${ }^{39}$. The topics, divided into thirteen chapters and in paragraphs, concern the classification and the most common properties of bodies, motion and forces, terrestrial elements and phenomenon, animal breathing and heat, static electricity.

The approach is still that typical of "Physica Generalis" that is, completely qualitative, with brief historical references to the physics of philosophers of ancient times compared to some protagonists of the science of the 1600s and 1700s. In his exposition Silio cites and points out that he knows important scientists of his time as Musschenbroek, Leeuwenhoek, Desaguliers, Hauksbee, Gravesande, Poleni, Franklin e Nollet. Starting from chapter V there are also, scattered and inserted in the text, fifteen illustrations of scientific instruments (Figures 21-23), drew by Taranto Rosso. The last two chapters, of only twenty pages, are about phenomena of static electricity and some simple measuring instruments ${ }^{40}$ such as Hauksbee's electrostatic machine, the electrophorus, Leida's bottles and batteries, the electrometers of Volta, Henley, Cavallo and Bennet, Coulomb's scale and the electric ringing.

The second book of the work is entitled "Essay about physical-mathematics. Second book of physics by sir D. Giovanni Silio, professor of physics at the Royal Academy of Studies in Caltagirone, 1820" (Figure 24). The manuscript is a remarkable didactic work thanks to its strong mathematical approach ${ }^{41}$, a characteristic ${ }^{39}$ Silio asserts: "The result of observations and experiments constitutes the experience. The orderly arrangement of experiments and observations with the purpose of explicating natural facts is experimental physics, the then orderly representation of the reasons of natural facts since they depend from observations and experiments constitutes theoretical physics. If mathematics is used to determine the quantity of matter, forces, effects, and everything else it can, physical mathematics is born..." (Silio Borremans, 1819: pp. 16-17).

${ }^{40}$ The text, even if it has specific areas, doesn't have the explicative illustrations of the instruments. The last page of chapter XIII, only begun, is incomplete, an unequivocal sign of the lack of other text.

${ }^{41}$ However, it is important to specify that the mathematics used in the text is rather elementary lacking, for example, the differential calculus. The tools used don't go beyond theory of proportions, algebra and basic geometry. 


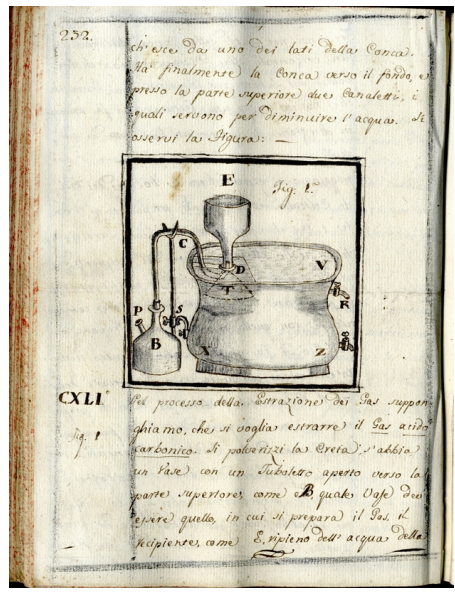

Figure 21. Silio's lecture course transcribed and drawn in 1819 by E. Taranto Rosso. Drawing of a pneumatic-chemical apparatus for extracting gases. By Courtesy of Municipal Library E. Taranto in Caltagirone.

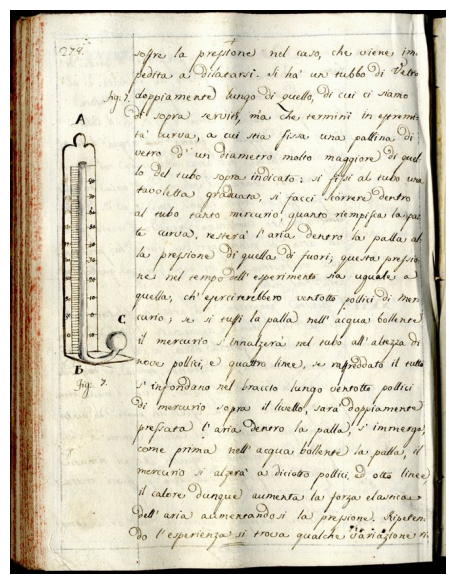

Figure 22. Silio's lecture course transcribed and drawn in 1819 by E. Taranto Rosso. Drawing of a mercury-filled air thermometer. By Courtesy of Municipal Library E. Taranto in Caltagirone.

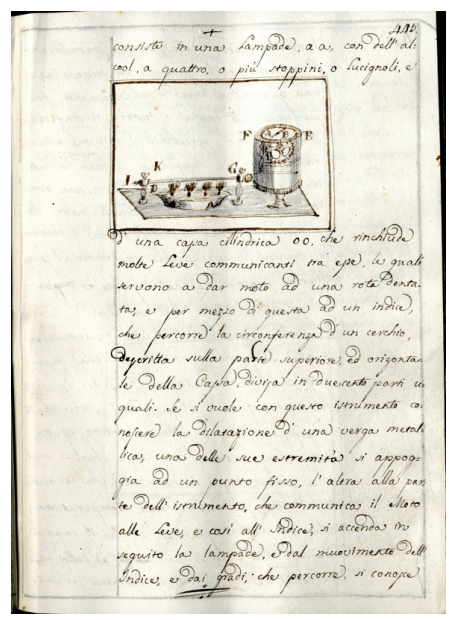

Figure 23. Silio's lecture course transcribed and drawn in 1819 by E. Taranto Rosso. Drawing of the dilatometer improved by Nollet. By Courtesy of Municipal Library E. Taranto in Caltagirone. 


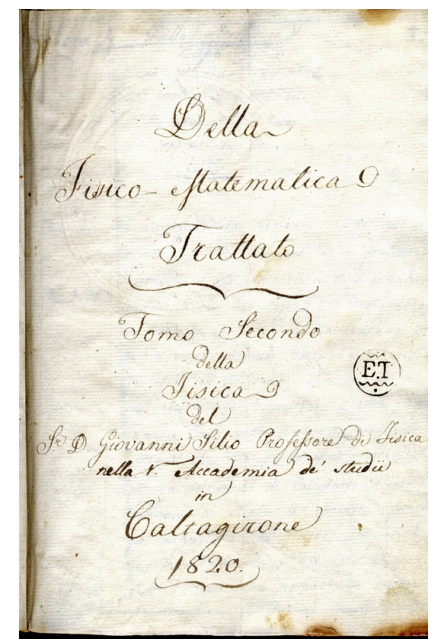

Figure 24. Manuscript frontispiece of Giovanni Silio's lecture course conducted in 1820 and transcribed by E. Taranto Rosso. By Courtesy of Municipal Library E. Taranto in Caltagirone.

that is rarely found in printed works of the time. The essay must be read as a direct testimony of the approach and methods used in teaching physical-mathematics ${ }^{42}$ in a provincial and decentralized university, as was the R. Academy of Caltagirone, before the reform of 1825. The course remains anchored to the tradition of the end of the 1700s, the so-called "mixed-mathematics" that mainly concerned mechanics, hydrostatics, hydraulics and optics, subjects that had already reached a formal mathematical structured compared to the younger Baconian sciences such as electricity, magnetism and heat. The teaching method was borrowed by that of pure mathematics whose conclusions had axioms and definitions as constructive foundations. Silio, who had the formation of a good mathematician, adopted the same explicative method in his dissertation. The formal structure of the theory, based on definitions, theorems and corollaries, had to bring to indisputable conclusions confirmed by few and selected experimental facts. The manuscript is divided into two parts and is characterized by having a rich iconography of images ${ }^{43}$ inserted in the text (Figures 25-27), to support calculations and geometrical demonstrations. The first part, of 289 pages, is divided into 27 chapters and is definitely the most interesting of the essay thanks to its strict mathematical approach. It mainly deals with the following subjects: motions and their compositions, gravity, machine's theory, hydrostatics, hydraulics, levels and aerometer, simple and compound pendulum, central forces, projectiles motion, theory of collisions. In many chapters Silio briefly describes some

\footnotetext{
${ }^{42}$ Physical-mathematics was also taught at the time at the University of Palermo by canon Diego Muzio (1772-1837) who died of cholera in 1837. Narbone informs about a manuscript text of his with the title Lessons of physical-mathematics dictated at the University of Palermo (Narbone, 1854: p. 16, Vol. III). After Muzio, Emmanuele Estiller (1797-1848) carried on the teaching in Palermo. Estiller produced the first text of physics-mathematics published in Sicily, the Elementary treatise on mathematical physics (Estiller, 1838: Palermo) which the author intended to publish in various volumes but, at last, remained incomplete.

${ }^{43}$ The images, all drawn by Taranto Rosso, are about 185 in total. This characteristic is very unusual for a scientific text of the first half of the 1800s.
} 


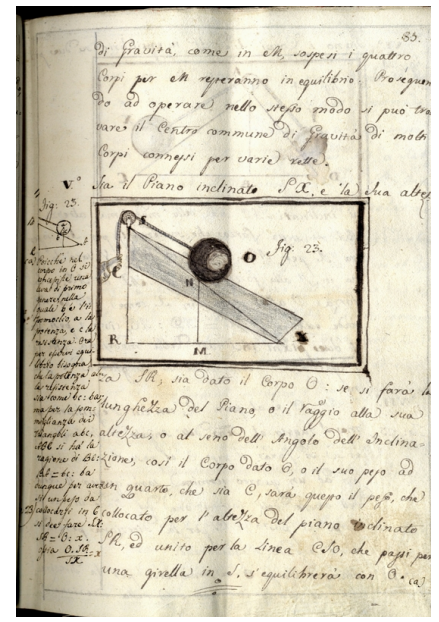

Figure 25. Silio's lecture course transcribed and drawn in 1820 by E. Taranto Rosso. Study of the equilibrium of a body on an inclined plane. By Courtesy of Municipal Library E. Taranto in Caltagirone.

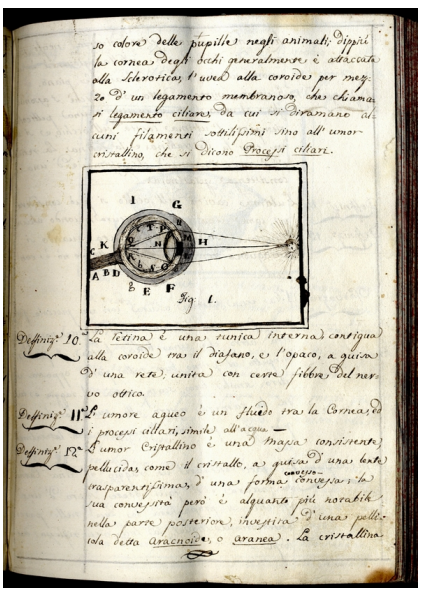

Figure 26. Silio's lecture course transcribed and drawn in 1820 by E. Taranto Rosso. The mechanism of vision through the internal structure of a human eye. By Courtesy of $\mathrm{Mu}$ nicipal Library E. Taranto in Caltagirone.

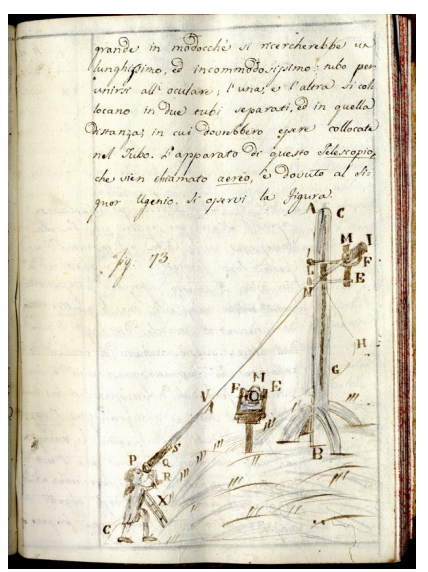

Figure 27. Silio's lecture course transcribed and drawn in 1820 by E. Taranto Rosso. Drawing of the Huygens aerial telescope. By Courtesy of Municipal Library E. Taranto in Caltagirone. 
experimental facts, of which he demonstrates the theory, then he goes to the direct verification of experiments. Thus in the case of bodies in free fall, due to gravity and of motion "equitably accelerated" Silio asserts:

"The propositions we demonstrated about the space covered by bodies subject to gravity prove to be uniform to experience using machines. You observed that invented by Nollet who was pushed by the example of Gravesande, but the best among those invented is the one of Sir Atwood" (Silio Borremans, 1820: p. 65).

In his accurate exposition of facts Silio would also like to describe the scientific instruments used in the experiments but he lacks the time ${ }^{44}$. With regard to physical quantities and forces, Silio correctly uses the concept of vector, its components and the parallelogram's rule. For example in the analysis of a body's motion on an inclined plane he correctly approaches the problem by decomposing the weight force ${ }^{45}$. Interesting is also the chapter dedicated to the general analysis of the central forces in curvilinear motion, separated into centrifugal and centripetal forces ${ }^{46}$. In particularly the study of planets' motion developed by using the theory of conics, is very accurate. It was a topic that Silio knew very well for having tought it in $1820^{47}$. The second part of the essay, of 184 pages, is divided into five chapters and is entitled "About the doctrine of light". The topics treated concern a general introduction to optics, catoptrics, classification of lenses (Figure 28), colours, telescopes, microscopes and some dioptric and catoptric machines. The general approach is quite discursive and certainly less mathematical than the first part of the essay. The geometrical and algebraic demonstrations, with the exception of the theory of lenses, are almost absent. Therefore, theorems are lacking, however a very linear expositive order, through the experienced schema of definitions and corollaries remains. The main value of the exposition lies in the rich apparatus of images drawn manually, they are about eighty, and they really facilitate the comprehension of topics. The chapter dedicated to colours is the most experimental one, because it is based on a detailed description of ten experiments carried out in a darkroom. With the help of a "scioptic ball" Silio studies the phenomena of refraction and dispersion of a solar ray combining prisms, lenses and thin laminas (Figure 29).

\footnotetext{
${ }^{44}$ After having treated one of the first topics, compound motion, Silio affirms: "The truths demonstrated could be verified through experiments using machines, Describing them would be time-consuming, I made you observe them, explaining the construction and use and the truth of the above propositions was seen; we will use the same method for the future" (Silio Borremans, 1820: pp. 22-23).

45" All the whole gravity which is considered in a free body is called absolute gravity, the part why it descends through an inclined plane is called relative gravity" and the component perpendicular to the plane "pressing gravity" (Silio Borremans, 1820: p. 67).

${ }^{46}$ Not infrequently small mistakes are found in the text. For example, about the centripetal force of a circular motion Silio writes $F=v^{2} / 2 r$ (Silio Borremans, 1820: p. 228).

${ }^{47}$ With regards to it, consult the manuscript kept in the shelf VII, manuscripts room, Municipal Library E. Taranto, Caltagirone, titled "Treatise on Conic Section according to the method of sir D." Giovanni Silio Public Professor of Sublime Physics Mathematics and Geometry at the Royal Academy of Studies in the city of Caltagirone, in A.D. 1820. For use of Emmanuele M. Taranto and Rosso student of superior Sciences" (Figure 30).
} 


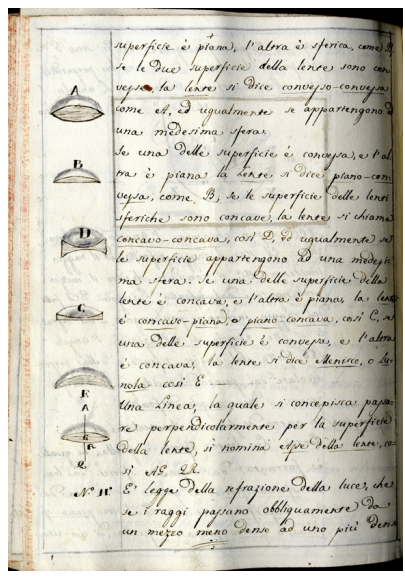

Figure 28. Silio's lecture course transcribed and drawn in 1820 by E. Taranto Rosso. Drawing showing the classification of lenses. By Courtesy of Municipal Library E. Taranto in Caltagirone.

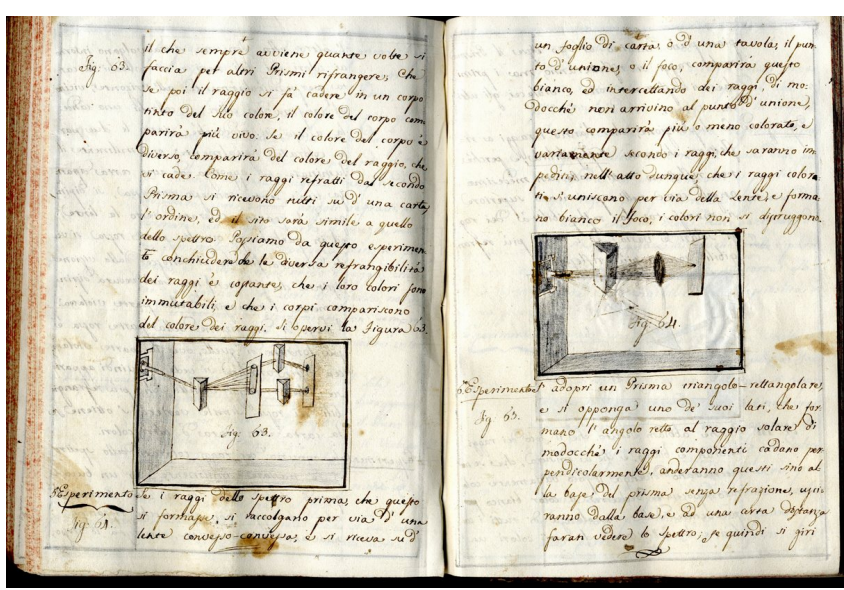

Figure 29. Silio's lecture course transcribed and drawn in 1820 by E. Taranto Rosso. Optical experiments with prisms and lens. By Courtesy of Municipal Library E. Taranto in Caltagirone.

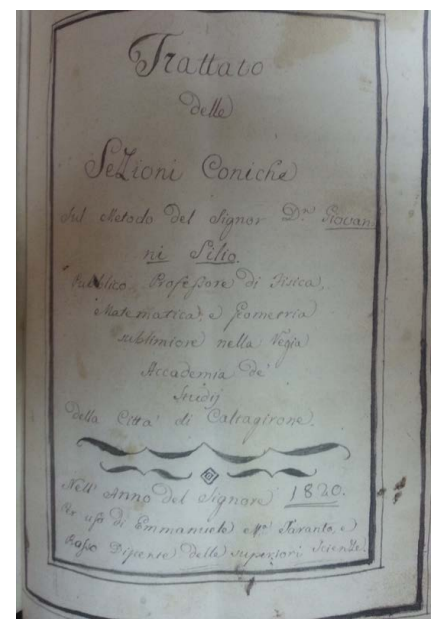

Figure 30. Frontispiece of the manuscript treatise by E. Taranto Rosso of 1820 entitled "Treatise of Conical Sections based on the Method of Mr. Giovanni Silio". By Courtesy of Municipal Library E. Taranto in Caltagirone. 
The chapter ends with a study extended to the big atmospheric phenomena; he particularly goes into a detailed explanation of the rainbow adducing some historical explication. The last topics treated shows some lacks of text and images and so they are incomplete, as if Silio didn't have enough time to conclude his course.

\section{Notes on the Manuscripts Consulted}

For the present work, a large number of unpublished manuscripts have been consulted at the Municipal Library "E. Taranto", manuscripts room, in Caltagirone. The records related to the whole Silio's corpus of manuscripts are collected on the shelves VII, XIII, XIV. These are the funds consulted for this study: funds “Randazzini V”, “Taranto's correspondence”, “Manoscritti Silio Guglielmo Corrispondenza varia”, "Varie Taranto", "Giovanni Silio's biographical notes". In particular, the following manuscripts have been consulted:

Institutiones Physicae Generalis et Particularis. The work has no a title (it was rebuilt thanks to a quotation by Taranto Rosso) and it is not dated (about the end of XVIII century). The work is divided into two parts: Philosophiae Naturalis Institutiones and Phisica Particularis.

Institutiones Physicae Generalis et Particularis. Incomplete copy, dated 1808 by a pupil of Silio, Josephi Strazzuso. The title page of the work contains the following text: “Ex meis manuscriptis D. Joseph Strazzuso. Ex Libris G. S. D ${ }^{\text {ris }} D^{n}$ Josephi Strazzuso Anno Domini Millesimo octinaentesimo octavo". On the next page there is the following note: "Cathedram moderante in $R$. Studiorum Academia Calatagirone Joanne Silio".

Codice. Della Fisica, o Filosofia Naturale dettata in Caltagirone da D. ${ }^{n}$ Giovanni Silio nel 1818. Copy of a Silio's pupil signed " $S$. M.". Under the title has been transcribed a poetic "Sonetto".

Della Fisica ossia Filosofia Naturale Trattato sul Metodo del Signor D. ${ }^{n}$ Giovanni Silio Professore di essa Scienza nella Regia Accademia de' Studi di Caltagirone. Tomo Primo. In Caltagirone scritta da Emmanuele M. ${ }^{a}$ Taranto, e Rosso nell Anno 1819.

Trattato delle Sezioni Coniche sul metodo del signor D. ${ }^{n}$ Giovanni Silio Pubblico Professore di Fisica Matematica e Geometria sublimiore nella Regia Accademia de' Studi della Città di Caltagirone. Nell Anno del Signore 1820. Per uso di Emmanuele M. ${ }^{a}$ Taranto e Rosso Discente delle superiori Scienze.

Della Fisico-Matematica Trattato. Tomo Secondo della Fisica del $S^{r} D$. Giovanni Silio Professore di Fisica nella R. Accademia de' Studi in Caltagirone 1820.

Trattato di Equazioni Composte Secondo il Metodo del Signor D. Giovanni Silio, Professore di Fisica, e Matematica Sublime nella $R$. Accademia di Caltagirone 1819-20. On the bottom of the page, handwritten, reads: "Da' Mss di Emmanuello Taranto Rosso".

(1827-1860), Royal Academy of Studies "Ferdinando" whose organization de- 
pends on the Commission of Education and Public Education which is resident in Palermo. Various news about the disciplines imparted in the said Academy and in other institutes; on the teachers ecc., manuscripts (miscellany with spread sheets), "Pubblica Istruzione e Cultura-Reale Accademia degli Studi-Scuole Sussidi e Borse di Studio" ${ }^{\circ}$ XXXII, fasc. 756, Municipal Library E. Taranto, Caltagirone.

(1831-1837) "Giornale per la R. Accademia degli Studi di Caltagirone incominciando da novembre 1831 sotto la direzione del Sig.r Cav. D. Emanuello Taranto Rosso"; book of bills dated 1/1/1832, manuscripts, room F. A., Shelf XIV, Pal a N. ord. 2.1, Municipal Library E. Taranto, Caltagirone.

(1842-1853), Royal Academy of Studies-Various, manuscripts (miscellany with spread sheets), Records, cat. 9, class 5, fasc. 3, Bibl. XXXII/1-759, Municipal Library E. Taranto, Caltagirone.

(1850), Royal Academy of Studies. Professors: qualifications and titles required, manuscripts (miscellany with spread sheets), Records, cat. 9, class 5, fasc. 3, Municipal Library E. Taranto, Caltagirone.

\section{Conflicts of Interest}

The authors declare no conflicts of interest regarding the publication of this paper.

\section{References}

Allotta, M. P., Di Maio, F., \& Romano, T. (2007). Scienziati in Sicilia: Dizionario di astronomi, chimici, fisici, matematici e naturalisti. Palermo: Istituto Magistrale Statale "Regina Margherita".

Cannella, S. (1784). Ragguaglio dei palloni aereostatici lavorati con felice successo da D. Ercole M. Branciforti e Pignatelli Principe di Pietraperzia. Palermo: Dalle stampe di Gaetano Maria Bentivegna.

Crimi, A. (1981). L'istruzione pubblica in Caltagirone dal 1570 al 1860 (pp. 90-101). Nuovi quaderni del meridione, anno XIX, n. 73, gennaio-marzo 1981.

Dollo, C. (1979). Filosofia e scienze in Sicilia. Padova: Cedam.

Estiller, E. (1838). Trattato elementare di Fisica Matematica. Meccanica. Tomo I, Palermo: Nella Reale stamperia.

Heubach, J. P. (1784). Des Ballons aérostatiques, de la manière de les construire, de les faire élever. Avec quelques vues pour les rendre utiles. On y a joint P histoire des ballons les plus singuliers, soit par la manière dont ils furent construits, soit par Pélévation où ils sont parvenus, \& leur capacité. Orné de planches en taille-douce. A Lausanne: chez J. P. Heubach \& Comp.

Mantovani, R., \& Bartolotta, D. (2016). The Collection of Historical Scientific Instruments of the Liceo "Bonaventura Secusio" in Caltagirone. In L. Fregonese, \& I. Gambaro (Eds.), Proceedings of the 33rd Annual Conference of the Italian Society for the History of Physics and Astronomy (pp. 193-206). Pavia: Pavia University Press.

Mira, G. M. (1881). Bibliografia siciliana: Ovvero gran dizionario bibliografico delle opere edite ed inedite, antiche e moderne di autori siciliani stampate in Sicilia e fuori. Opera indispensabile ai cultori delle patrie cose non che ai librai ed agli amatori di libri (Vol. II). Palermo: Arnoldo Forni Editore (ristampa anastatica 1973). 
Narbone, A. (1851). Bibliografia sistematica o apparato metodico alla storia letteraria della Sicilia (Vol. II). Palermo: Stamperia di Giovanni Pedone.

Narbone, A. (1854). Bibliografia Sicola sistematica o apparato metodico alla storia letteraria della Sicilia (Vol. III). Palermo: Stamperia dei fratelli Pedone Lauriel.

Narbone, A., \& Taranto Rosso, E. (1871). Bibliografia calatina tratta dalla bibliografia sicola sistematica di Alessio Narbone con Aggiunte di Emmanuello Taranto. Caltagirone: Stamperia A. Giustiniani.

Pitrè, G. (1904). La vita in Palermo cento e più anni fa (Vol. II). Firenze: G. Barbera Editore.

Scinà, D. (1827). Prospetto della Storia letteraria di Sicilia nel secolo decimottavo dell Abate Domenico Scinà regio storiografo (Vol. III). Palermo: Dalla Tipografia Reale di Guerra.

Scinà, D. (1859). Prospetto della storia letteraria di Sicilia del secolo decimottavo (Vol. unico, Tomo I). Palermo: Officio Tipografico Lo Bianco.

Scorsone, A. (1987). Scienziati siciliani dell evo moderno: Alcuni profili bio-bibliografici. Palermo: Tarantello.

Silio Borremans, G. (1787). Osservazioni critiche su i nuovi elementi di analisi dell ab. Nicolai opera di Guglielmo Silio Borremans professore di analisi nella reale Accademia Militare. Napoli: Presso Donato Campo regio stampatore.

Silio Borremans, G. (1790). Teoria su la direzione degli areostati. Memoria postuma di Giovanni Silio e Borremans (pp. 162-177). Giornale di Scienze Lettere e Arti per la Sicilia diretto dal Bar. V. Mortillaro, Vol. 76, Anno 19 (Ottobre, novembre, dicembre), 1841. Palermo: Presso la Stamperia Oretea.

Silio Borremans, G. (1792). Saggio sulp influenza dell analisi nelle scienze politiche ed economiche applicata a' contrabandi (pp. 89-173). Nuova Raccolta di opuscoli di autori siciliani, Tome V. Palermo: Per le stampe di Solli.

Silio Borremans, G. (1819). Della Fisica ossia Filosofia Naturale Trattato sul Metodo del Signor D.n Giovanni Silio Professore di essa Scienza nella Regia Accademia de' Studi di Caltagirone. Tomo Primo. In Caltagirone scritta da Emmanuele M.a Taranto, e Rosso nell'Anno 1819.

Silio Borremans, G. (1820). Della Fisico-Matematica Trattato. Tomo Secondo della Fisica del S.r D. Giovanni Silio Professore di Fisica nella R. Accademia de' Studi in Caltagirone 1820 .

Taranto Rosso, E. (1841). Cenni biografici di Giovanni Silio (pp. 158-162). Giornale di Scienze Lettere e Arti per la Sicilia diretto dal Bar. V. Mortillaro, Vol. 76, Anno 19 (Ottobre, novembre, dicembre). Palermo: presso la Stamperia Oretea.

Taranto Rosso, E. (1857). La festa del Conte in Caltagirone. Catania: Tip. di Crescenzo Galatola.

Villari, L. (1980). La comarca e Puniversità degli Studi di Piazza Armerina (con cenni sulle comarche e sulle altre università di Sicilia). Grottaferrata (Roma): Scuola tipografica Italo-Orientale "S. Nilo". 